\title{
PENGEMBANGAN MODEL INKUIRI MORAL PADA PEMBELAJARAN MENULIS POSTER KONTEKS MULTIKULTURAL DALAM PEMBENTUKAN KARAKTER
}

\author{
SUHENDRO \\ SMP Negeri 1 Tanjung, Brebes, Jawa Tengah \\ e-mail : hendro0568@gmail.com
}

\begin{abstract}
ABSTRAK
Kemampuan menulis poster dalam konteks multikultural di sekolah memiliki peranan penting untuk meningkatkan pemahaman peserta didik dalam hidup masyarakat dan berbudaya secara nyata.Untuk memenuhi hal tersebut, diperlukan adanya model pembelajaran menulis poster yang dapat menciptakan sistem belajar menarik, menyenangkan, dan berorientasi pada penerapan nilai-nilai moral dalam rangka pembentukan karakter. Bertolak dari pentingnya kemampuan menulis poster yang konteks multikultural dalam pembentukan karakter peserta didik, maka diadakan penelitian. Permasalahan penelitian ini adalah apakah desain model inkuiri moral pada pembelajaran menulis poster dapat meningkatkan prestasi belajar dan sekaligus dalam pembentukan karakter peserta didik. Desain penelitian dan mengembangan (research and developmen) ini dikelompokkan dalam tiga bagian yaitu, studi pendahuluan, pengembangan, dan uji validasi. Analisis data dilakukan dengan analisis deskripsi kualitatif dan kuantitatif. Hasil penelitian ini dapat disimpulkan bahwa model inkuiri moral pembelajaran menulis poster konteks mutikultural dalam pembentukan karakter sebagai produk pengembangan ini terbukti efektif. Indikatornya adalah meningkatnya rata-rata nilai dan meningkatkan sikap / perilaku positif terhadap mata pelajaran. Berdasarkan temuan tersebut, guru dalam proses belajar mengajar hendaknya bisa lebih kreatif dan aplikatif dalam menggunakan model-pembelajaran dalam rangka membangun manusia cerdas intelektual dan emosi.
\end{abstract}

Kata Kunci: Model Inkuiri Moral, Konteks multikultural, Karakter

\section{PENDAHULUAN}

Perkembangan masyarakat yang sangat dinamis serta masalah-masalah moral yang dewasa ini terus berkembang membutuhkan perhatian dan kepekaan dari seluruh elemen bangsa tidak hanya dari para pakar dan pemerhati masalah moral. Namun, juga dunia pendidikan yang mempunyai peran sangat strategis sebagai wahana dan agent of change bagi masyarakat. Kondisi masyarakat Indonesia yang sangat plural baik dari aspek suku, ras, agama serta status moral memberikan kontribusi yang luar biasa terhadap perkembangan dan dinamika dalam masyarakat.

Maraknya tindak kekerasan di tengah masyarakat karena perbedaan etnis, agama, dan kecemburuan sosial. Timbulnya demontrasi yang disertai perusakan, pembakaran, dan bentrokan antarkelompok baik di tingkat pusat maupun daerah. Sejalan dengan itu, Rahmat (2008) memandang betapa pentingnya memberikan porsi pendidikan multikultural sebagai wacana baru dalam sistem pendidikan di Indonesia, baik melalui substansi maupun model pembelajaran. Hal ini sangatlah urgen untuk memberikan pembekalan dan membantu perkembangan wawasan pemikiran dan kepribadian serta melatih kepekaan peserta didik dalam menghadapi gejala-gejala dan masalah-masalah moral yang terjadi pada lingkungan masyarakatnya.

Untuk itu, pengembangkan kemampuan menulis poster dalam konteks multikultural yang diharapkan dapat meningkatkan pemahaman para peserta didik dalam hidup bermasyarakat dan berbudaya secara nyata. Oleh karena itu, perlu model pembelajaran yang tepat untuk mensinergiskan antara materi konteks multikultural dan model. Model inkuiri merupakan model pembelajaran yang berupaya menanamkan dasar-dasar berpikir ilmiah pada peserta didik sehingga dalam proses pembelajaran ini peserta didik lebih banyak belajar 
sendiri, mengembangkan kreativitas dalam masalah. Peserta didik benar-benar ditempatkan sebagai subjek yang belajar, maka penggunaan model pembelajaran menulis poster konteks multikultural yang menanamkan nilai-nilai kebersamaan, gotong-royong, menghargai, menerima, budi perkerti, dan sebagainya.

Salah satu kompetensi menulis yang menjadi perhatian dalam penelitian ini adalah menulis poster. Dalam pelaksanaan pembelajaran selama ini, guru cenderung membelajarkannya dalam konteks terbatas. Menulis poster hanya diimplementasikan sebagai media sarana informasi saja. Tujuan menulis poster hanya sekadar menawarkan produk dan jasa, yang menunjukkan bahwa pembelajaran bahasa Indonesia masih terpaku pada kurikulum dan buku teks. Pendidikan multikultural belum mendapat perhatian dari sekolah padahal peserta didik berasal dari ragam etnik yang berbeda, di antara, Tionghoa, Batak, Arab, Sunda, dan Jawa.

Pembelajaran bahasa diharapkan membantu peserta didik mengenal dirinya, budayanya, dan budaya orang lain, mengemukakan gagasan, berpartisipasi dalam masyarakat yang menggunakan bahasa tersebut, dan menemukan serta menggunakan kemampuaan analitis dan imaginatif yang ada dalam dirinya. (Depdiknas 2006: 231). Untuk mencapai tujuan tersebut pembelajaran bahasa harus memberikan kesempatan seluas-seluasnya kepada peserta didik untuk bergaul dan berekspresi akan dirinya, budaya orang lain.

Pendidikan multikultural merupakan sebuah kebijakan sosial yang didasarkan pada prinsip-prinsip pemeliharaan budaya dan saling memiliki rasa hormat antara seluruh kelompok budaya di dalam masyarakat. Dalam masyarakat Indonesia yang multikultural dibutuhkan manusia yang cerdas dan bermoral yang hanya dapat diciptakan melalui proses pendidikan (Tilaar 2004: 16), yakni pendidikan multikultural. Pendidikan multikultural bertujuan memberikan peluang dan pelayanan pendidikan yang sama bagi peserta didik dari berbagai ras, etnis, kelas sosial, dan kelompok budaya. Salah satu sasaran pendidikan multikultural adalah agar peserta didik di dalam pembelajaran mendapat ilmu, sikap, dan kompetensi yang berfungsi efektif dalam sebuah masyarakat demokrasi yang pluralis.

Pendidikan multikultural dapat diintegrasikan dalam pembelajaran bahasa Indonesia karena bahasa Indonesia memiliki peran dan fungsi strategis untuk mencerdaskan peserta didik dengan membuka wawasan pengetahuan dan keragaman budaya masyarakat sekitarnya dan dunia. Implementasi peran dan fungsi bahasa Indonesia yang dapat mengangkat derajat masyarakat Indonesia ini memerlukan model pengembangan pembelajaran bahasa Indonesia sehingga para guru tidak terpaku pada fungsi bahasa Indonesia yang pertama yaitu sebagai alat komunikasi, tetapi mereka dapat membuka diri dan mengembangkan potensi untuk mengembangkan kompetensi peserta didik dalam pembelajaran bahasa Indonesia. Pembelajaran bahasa Indonesia berkonteks multikultural ini sekaligus dapat diarahkan untuk pembentukan karakter peserta didik, yaitu karakter yang sesuai dengan jati diri bangsa kita, antara lain berketuhanan, jujur, adil, disiplin, bertanggung jawab, bijaksana, sosial, toleran, bangga terhadap bahasa dan bangsanya, dan sebagainya. Dengan demikian, pendidikan multikultural efektif digunakan untuk pembentukan karakter peserta didik. Dalam hal ini, materi ajar dan pembelajaran bahasa Indonesia perlu dan penting untuk dikembangkan dalam konteks multibudaya di dalam masyarakat multikutural.

Pentingnya materi ajar dalam pembelajaran bahasa Indonesia konteks multibudaya berkaitan dengan (1) hakikat belajar bahasa, (2) tujuan pembelajaran bahasa Indonesia, dan (3) fungsi pembelajaran bahasa Indonesia. Belajar bahasa hakikatnya adalah belajar berkomunikasi dan belajar sastra adalah belajar menghargai manusia dan nilai-nilai kemanusiaannya. Adapun pendapat Nurhadi (2003: 19) tentang tujuan pembelajaran bahasa Indonesia, maka tujuan utama pembelajaran menulis kreatif yang dikembangkan di dalam penelitian ini adalah mengembangkan perilaku bahasa dan perilaku sosial budaya pembelajar. Indikator pembelajarannya adalah (1) peserta didik mampu menulis secara kreatif dalam bahasa Indonesia yang baik dan benar dalam berbagai ranah sosial yang sesuai dengan fungsi bahasa Indonesia di masyarakat, (2) peserta didik mampu menunjukkan perilaku berbahasa 
yang sesuai dengan norma sosial budaya, antara lain santun berbahasa, berkomunikasi dengan sesama teman, dan berkomunikasi dengan teman yang berbeda budaya, nilai dan keyakinan, (3) peserta didik mampu menghargai perbedaan budaya, nilai dan keyakinan, dan (4) memiliki sikap tenggang rasa dalam memecahkan masalah dengan teman. Selain itu, pembelajaran bahasa Indonesia juga dituntut mampu mengembangkan konsep-konsep berbagai ilmu pengetahuan untuk mengantarkan masyarakat dan bangsa Indonesia menuju ke arah peradaban dan kehidupan modern sesuai dengan tingkat kemajuan ilmu pengetahuan dan teknologi mutakhir (Alwi 2002: 4).

Dalam upaya mengembangkan kemampuan menulis poster dalam konteks multikultural yang diharapkan dapat meningkatkan pemahaman para peserta didik dalam hidup bermasyarakat dan berbudaya secara nyata, materi pembelajaran menulis perlu dikembangkan dengan konteks multikultural, sehingga peserta didik lebih kreatif mengekspresikan ide gagasannya dalam bentuk poster. Model pembelajaran yang digunakan adalah inkuiri sosial sebagai dasar model inkuiri moral. langkah-langkah pembelajaran inkuiri moral merupakan suatu siklus yang dimulai dari (1) observasi atau pengamatan terhadap berbagai fenomena alam, (2) mengajukan pertanyaan tentang fenomena yang dihadapi, (3) mengajukan dugaan atau kemungkinan jawaban, (4) mengumpulkan data berkait dengan pertanyaan yang diajukan, dan (5) merumuskan kesimpulan berdasarkan data.

Kejelian guru dalam membidik tujuan tersebutpun dapat ajarkan dengan konteks multikultural yang berkaitan dalam membentuk karakter. Di tengah kebangkrutan moral bangsa, maraknya tindak kekerasan, inkoherensi politisi atas retorika politik, dan perilaku keseharian, pendidikan karakter yang menekankan dimensi etis-religius menjadi relevan untuk diterapkan. Menurut Jakoep Ezra (dalam Dhuri 2009) karakter dibentuk tidak diciptakan, harus melalui proses. Untuk mengembangkan karakter, diperlukan pendidikan karakter. Dalam hal ini guru perlu latar belakang peserta didik yang berbeda-beda ( etnis, bahasa, sosial, ekonomi, agama, suku,dsb). Sebagai fasilitator guru perlu menghubungkan kedua hal di atas dalam sebuah pembelajaran. Konsepnya adalah kemampuan menulis poster secara kreatif dengan konteks multikultural dalam membentuk karakter peserta didik

\section{METODE PENELITIAN}

Penelitian ini mengadopsi desain penelitian dan pengembangan pendidikan (educational research \& development) yang menurut Borg \& Gall (dalam Sukmadinata 2008 ). Kesembilan langkah tersebut adalah (1) research and information collecting, yaitu studi literatur, observasi, dan persiapan, (2) planning, yaitu penentuan tujuan yang akan dicapai, (3) develop preliminary form of produk, yaitu mengembangkan bentuk permulaan dari produk pada setiap tahapan, (4) preliminary field testing, yaitu uji coba lapangan awal dalam skala terbatas, (5) main product revision, yaitu perbaikan terhadap produk awal, (6) main field testing, yaitu uji coba utama, (7) operation product revision, yaitu perbaikan dan penyempurnaan dari uji coba utama, (8) operational field testing, yaitu uji validasi terhadap produk opersional yang telah dihasilkan, (9) final product revision, yaitu perbaikan akhir terhadap produk yang telah dikembangkan. 


\section{TAHAP 1: PENDAHULUAN}

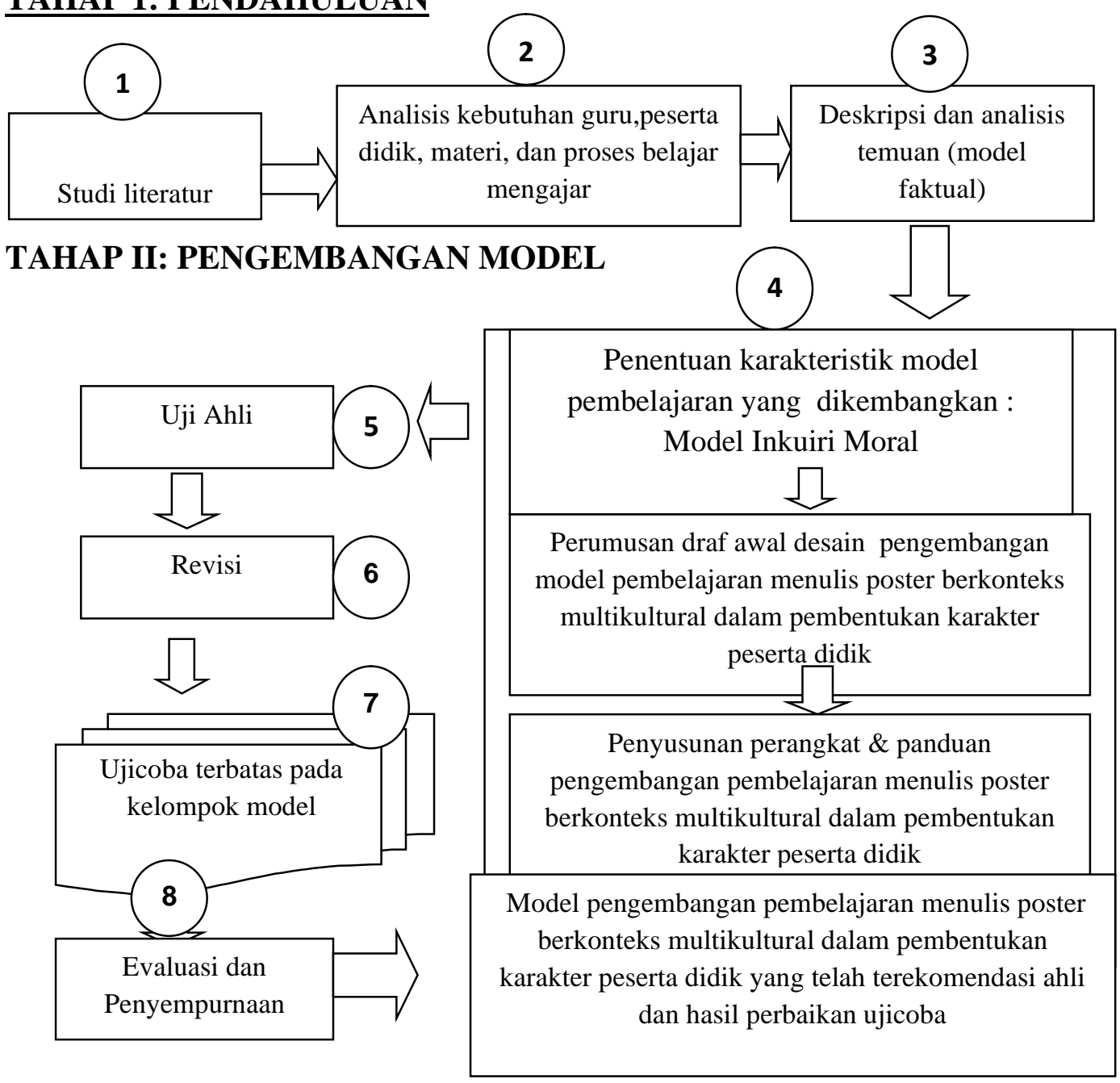

\section{TAHAP III: PENYUSUNAN DRAF FINAL}

\section{HASIL PENELITIAN DAN PEMBAHASAN}

\section{Pengembangan Materi}

Pembelajaran bahasa Indonesia perlu dikaitkan dengan berbagai budaya yang ada di masyarakat. Penanaman nilai-nilai moral dalam rangka membangun etika. Pengembangan keterampilan peserta didik. Peserta Didik memiliki latar belakang etnik, budaya, adat, bahasa, dan agama yang berbeda-beda. Guru memiliki kepedulian terhadap kegiatan bermuatan multikultural.

\section{Pengembangan Silabus}

Ruang lingkup materi menulis poster berdasarkan peristiwa/ pengalaman yang pernah dialami peserta didik. Belajar untuk mengembangkan kemampuan ranah kognitif, psikomotor, dan apektif.

\section{Pengembangan Rencana Pelaksanaan Pembelajaran (RPP)}

Penyusunan rencana pelaksanaan pembelajaran (Silabus/RPP) menulis poster pengenalan ke arah keragaman budaya. Sumber belajar dari majalah, internet, dan buku teks. Media yang digunakan internet, majalah, gambar, dan VCD.

\section{Pengembangan Evaluasi Pembelajaran}

Penilaian bersifat menyeluruh terhadap hasil belajar peserta didik yang meliputi kognitif, psikomotor, sikap, dan nilai (afektif) yang direfleksikan dalam kebiasaan berpikir dan bertindak. Penilaian harus bersifat adil dengan tidak membeda-beda latar belakang sosial, budaya, ekonomi, agama, bahasa, dan gender. Bentuk soal dalam penilaian uraian dan portofolio. 


\section{Pelaksanaan Pembelajaran}

Apersepsi mengaitkan materi dengan realitas kehidupan/budaya peserta didik. Dalam melaksanakan pembelajaran ditayangkan contoh-contoh poster berkonteks multikultural. Pembelajaran berpusat pada kegiatan peserta didik. Pembelajaran memberikan kesempatan kepada peserta didik untuk bekerja sama dalam membangun pemahaman dan keterampilan melalui interaksi dengan lingkungan peserta didik. Metode yang digunakan diskusi dan presentasi. Pengorganisasian kelas peserta didik secara berkelompok. Dalam pelaksanaan di kelas guru menginternalisasikan nilai-nilai keuniversalan.

\section{Implementasi Model Inkuiri Moral Pembelajaran Menulis Poster Konteks Multikultural.}

Soekamto (dalam Trianto 2007: 1) mengemukakan maksud dari model pembelajaran adalah: "Kerangka konseptual yang melukiskan prosedur yang sistematis dalam mengorganisasikan pengalaman belajar untuk mencapai tujuan belajar tertentu,dan berfungsi sebagai pedoman bagi para perancang pembelajaran dan para pengajar dalam merencanakan aktivitas belajar mengajar." Hal ini sejalan dengan apa yang dikemukakan oleh Sudrajat (2008) model pembelajaran pada dasarnya merupakan bentuk pembelajaran yang tergambar dari awal sampai akhir yang disajikan secara khas oleh guru.

Model pembelajaran menulis poster berkonteks multikultural dalam pembentukan karakter peserta didik ini meliputi: (a) tujuan, (b) tahapan, (c) prinsip reaksi, (e) sistem pendukung, dan efek instruksional. 'Pelaksanaan pembelajaran menulis poster dengan model inkuiri moral bertujuan melibatkan peserta didik dalam mengeksplorasi suatu masalah moral dalam kehidupan beraneka ragam budaya agar dapat menghargai perbedaan agama, sosial, etnis, bahasa, dan gender. Dengan demikian diharapkan peserta didik mampu (1) mengembangkan sikap dan terampil masalah-masalah moral dan mengambil keputusan secara adil, (2) mengembangkan kemampuan berpikir logis, kreatif, dan kritis, (3) memberikan kebebasan atau otonomi pada peserta didik dalam hal menyusun pertanyaan dan mengemukakan pendapat secara verbal, dan (4) menghargai perbedaan budaya, nilai, dan keyakinan sehingga pendidikan multikultural dapat membangun karakter peserta didik.

\section{Panduan Pelaksanaan Pembelajaran Menulis Poster}

Model pembelajaran adalah kerangka konseptual yang melukiskan prosedur yang sistematis dalam mengorganisasikan pengalaman belajar untuk mencapai tujuan belajar tertentu dan berfungsi sebagai pedoman bagi para perancang pembelajaran dan para pengajar dalam merencanakan dan melaksanakan aktivitas pembelajaran. Hal ini sejalan dengan Eggen dan Kauchak (dalam Trianto 2007: 5) bahwa model pembelajaran memberikan kerangka dan arah bagi guru untuk mengajar. Desain pembelajaran menulis poster konteks multikultural terdiri atas enam tahap. Enam tahap tersebut adalah tahap orientasi, hipotesis, definisi, eksplorasi, pembuktian, dan generalisasi.

\section{a. Orientasi}

Tahap orientasi yaitu suatu tahapan untuk mengobservasi ide-ide yang dimiliki peserta didik sebelum pembelajaran. Hal ini bertujuan untuk memberi kesempatan pada peserta didik untuk mengembangkan motivasinya dalam mempelajari suatu topik yang hendak dipelajari. Pada tahap ini peserta didik diharapkan dapat menyadari adanya suatu Ilustrasi dalam berkonteks pembelajaran dan lingkungan. Selanjutnya peserta didik merumuskan Ilustrasi yang akan dipecahkan.

Pemanggilan ide atau gagasan dapat melalui langkah-langkah sebagai berikut:

(a) Guru menentukan tema berdasarkan kurikulum, minat, pengetahuan peserta didik, atau pertimbangan tertentu. 
(b) Guru mengadakan tanya jawab dengan peserta didik dalam menggali ide , pengalaman, minat, hobi, dan skemata peserta didik yang berhubungan dengan tema secara tertulis atau lisan dengan tidak mengadakan koreksi atas jawaban peserta didik.

(c) Mengelompokkan jawaban yang relevan dengan tema berdasarkan tanya jawab yang dilakukan. Kemudian guru bersama peserta didik secara berkelompok atau individu menentukan topik yang digemari sesuai kurikulum dan mengandung wawasan multikultural.

\section{b. Hipotesis}

Pada tahap hipotesis, peserta didik ditayangkan contoh poster berkonteks multikultural tentang ranah agama, moral, bahasa, gender, dan etnik. Peserta didik menyimak dan serta menangkap topik yang terdapat ilustrasi sebagai bahan untuk menemukan topik yang mereka alami yang berada pada lingkungan sekolah. Setelah itu peserta didik menentukan topik/masalah, kemudian merumuskan jawaban sementara atau hipotesis. Hal yang dilakukan guru untuk memancing jawaban peserta didik adalah dengan memberikan pertanyaan kepada peserta didik seputar masalah yang sedang dihadapi. Dari semua gagasan yang ada, dipilih salah satu hipotesis yang relevan dengan permasalahan yang diberikan. Berdasarkan pertanyaan dan jawaban, peserta didik dapat merumuskan hipotesis. Pada tahap hipotesis guru mengarahkan peserta didik untuk memberikan jawaban sementara dengan singkat mengenai masalah-masalah yang diberikan guru sebelumnya yaitu ilustrasi pertama, persoalan apa sajakah pada ilustrasi tersebut; kedua, nilai- nilai apa sajakah yang terdapat pada ilustrasi; ketiga, bagaimanakah caranya ilustrasi tersebut diubah menjadi sebuah poster? kemudian mereka menuliskan jawaban sementara pada buku catatan.

\section{c. Definsi}

Pada tahap ini peserta didik menjelaskan istilah-istilah yang digunakan dalam merumuskan hipotesis kepada guru dan teman-temannya. Berikut ini adalah skenario pembelajarannya. Untuk menguji apakah hipotesis mereka memenuhi syarat para peserta didik berkelompok, masing-masing 4-5 orang. Masing-masing kelompok menamakan dirinya dengan kata-kata universal seperti toleransi, moral, peduli, kejujuran, gotongroyong, kebersamaan, setia kawan, dan sebagainya. Dengan bimbingan guru, para peserta didik dalam tiap-tiap kelompok membahas maksud tentang poster berkonteks multikultural dan menentukan jawaban sementara (hipotesis), sehingga mereka memiliki pengertian yang sama tentang poster yang berkaitan dengan ranah agama, moral, bahasa, gender, dan etnik. Pada tahap ini paserta didik curah pendapat untuk memperoleh jawaban dari persoalan yang diberikan oleh guru. Suasana kegiatan belajar mengajar sangat menyenangkan. Peserta didik bersemangat mengikuti pada tahap ini.

\section{d. Eksplorasi}

Peran yang dilakukan guru untuk membantu dan membimbing peserta didik dalam kegiatan eksplorasi adalah berperan sebagai pemantau dalam proses pengumpulan data. Pada tahap ini guru memaparkan topik-topik yang ada pada ilustrasi. Peserta didik mencatat topik-topik tersebut sesuai dengan persoalan yang mereka hadapi sehingga dapat dipecahkan. Selanjutnya mereka mencari sumber dari internet, bertanya, dan buku teks, sebagai data untuk menulis poster berkonteks multikultural serta sekaligus menentukan unsur nilai moral yang ingin disampaikan.

\section{e. Pembuktian}

Pengarahan terhadap peserta didik sangat membantu dalam melakukan pembuktian hipotesis. Strategi ini dilaksanakan dengan memberikan daftar pengecekan perbaikan dan rambu-rambu pertanyaan evaluatif untuk menuntun dan memudahkan peserta didik melakukan perhatian terhadap pembuktian hipotesis yang telah dikemukakan. Pada tahap ini peserta didik mengumpulkan data-data sebagai dasar untuk 
menguji hipotesis. Guru membimbing peserta didik untuk menguji hipotesis. Peserta didik curah pendapat pada kelompoknya masing-masing, apakah hipotesis ditolak atau diterima secara empiris.

\section{f. Generalisasi}

Peserta didik merumuskan simpulan dan menarik generalisasi terhadap masalah yang sedang dipelajari. Peran guru dalam proses ini adalah mengajukan pertanyaanpertanyaan seputar masalah untuk membantu peserta didik menggeneralisasikan masalah yang ada. Guru memberi penilaian terhadap unjuk kerja dan produk telah dibuat kelompok serta penghargaan bagi tiga kelompok yang terbaik.

\section{g. Refleksi}

Guru mempersilakan beberapa peserta didik kesan pembelajaran secara umum dan menyampaikan informasi tindak lanjut pembelajaran menulis poster berkonteks multikultural dengan harapan bersikap bijak dalam menghadapi persoalan-persoalan kehidupan yang beraneka ragam.

\section{SIMPULAN DAN SARAN}

Produk penelitian pengembangan berupa model inkuiri moral pembelajaran menulis poster berkonteks multikultural dalam pembentukan karakter ini merupakan produk pengembangan yang disusun dan dikembangkan peneliti melalui serangkaian penilaian dari ahli dan guru. Produk pengembangan yang dihasilkan berupa pengembangan model inkuiri moral pembelajaran menulis poster yang berupa prinsip-prinsip model inkuiri moral, desain model inkuiri moral, karakteristik model pengembangan, perangkat pembelajaran yang berisi kompetensi dan kompetensi dasar, silabus, RPP, pedoman penilaian, dan VCD pembelajaran. Model ini mempunyai ciri khusus dengan mengaplikasikan komponen model inkuiri moral yaitu : bertanya, inkuiri, kisah/ilustrasi, masyarakat belajar, konstruktivisme,dan refleksi, dan penilaian.

Model inkuiri moral pembelajaran menulis poster berkonteks dalam pembentukan karakter sebagai produk pengembangan ini terbukti efektif dapat meningkatkan hasil pembelajaran kompetensi menulis poster . Hal tersebut tampak pada: (1)meningkatnya skor tes akademik, (2) meningkatkan kontak psikoakademis pembelajar, (3) memperkuat keyakinan diri, (4) meningkatkan motivasi belajar secara intrinsik, (5) meningkatkan sikap positif dalam belajar, (6) meningkatkan kemampuan dan strategi bernalar secara kritis, (7) meningkatkan sikap dan perilaku positif terhadap mata pelajaran serta para guru selama berlangsungnya pembelajaran. Maka dapat disimpulkan bahwa model inkuiri moral pembelajaran menulis poster berkonteks multikultural dalam pembentukan karakter efektif karena menumbuhkan sikap toleransi, kebersamaan, kekeluargaan, keadilan, dan menghargai dalam hidup keberagaman etnis, agama, ras, dan antargolongan, sehingga tercipta kehidupan yang tentram.

\section{DAFTAR PUSTAKA}

Alwi, Hasan. 2002. "Pemberdayaan Bahasa Indonesia dalam Mengadapi Kemungkinan Timbulnya Kecemburuan Global". Makalah disajikan dalam Seminar Internasional Prospek Pengembangan Kajian Indonesia dalam Konteks Kemajemukan Budaya, 25 Juni 2002, di Hotel Patrajasa Semarang.

Depdiknas. 2006. Kumpulan Permendiknas tentang Standar Nasional Pendidikan (SNP) dan Panduan KTSP. Jakarta: Dirjen Dikdasmen.

Dhuhri, Saifuddin.2009. Pendidikan Karakter sebagai Solusi Memajukan Bangsa . http://www.acehinstitute. ora/. Diunduh Jumat, 26 Juni 2009. 
Nurhadi. (2004). Bagaimana Meningkatkan Kemampuan Membaca. Bandung: Sinar Baru Algensindo.

Rahmat, Pupu Saeful. 2008. Wacana Pendidikan Multikultur di Indonesia. http;//akhmadsudrajat.wordpress.com/. Unduh Jumat 10 Juli 2009.

Sudradjat, Ahmad. 2008. Pengertian Pendekatan, Strategi, Metode, Teknik, Taktik, dan Model Pembelajaran. http://www.psma.org. Diunduh 7 Juli 2009.

Sukmadinata, Nana Syaodih. 2008. Metode Penilitian Pendidikan. Bandung: Remaja Rosdakarya

Tilaar, H.A.R. 2004. Multikulturalisme, Tantangan-Tantangan Global Masa Depan dalam Transformasi Pendidikan Nasional. Jakarta : Gramedia Widiasarana Indonesia.

Trianto. 2007. Model-model Pembelajaran Inovatif Berorientasi Konstruktivistik. Jakarta : Prestasi Pustaka Publisher. 